\title{
¿CÓMO SE BORDA LA POÉTICA DEL ABANDONO?
}

\author{
HOW IT OVERBOARD THE POETICS OF ABANDONMENT?
}

\author{
Claudia Arellano Hermosilla \\ Universidad academia de humanismo \\ cristiano (Santiago de Chile)
}

\section{Resumen:}

La "Poética del abandono", se basa en una expresión enunciativa del cuerpo-mujer, que está atravesada por elementos que rescatan o rearticulan la representación de sectores postergados dentro de un espacio que, históricamente en Occidente, es representado por la Historia, la Iglesia, el Estado y el Padre, en tanto autoridades en el recuento de narrativas sobre el pasado y el consecuente rol que tales relatos poseen en la fractura de identidades y memorias colectivas y de género.

El texto que viene a continuación, articula los diferentes abandonos, tanto físicos como simbólicos que han experimentado las mujeres en su devenir existencial, y que se manifiestan en la escritura desarrollada por las poetas del Sur de Chile, quienes buscan, montan y desmontan nuevas identidades a partir del trabajo literario.

\section{Palabras claves:}

Abandono, poética femenina, culpabilidad, montaje

\section{Abstract:}

The "Poetic of abandon" is based on an expression declarative of the body-woman, which is crossed by elements that rescue or reshaped the representation of sectors neglected within of an space, which historically in West, is represented by the history, the Catholic Church, the State and the Father, while authorities in counting the narratives about the past and the consequent role that these stories have in the fracture of identities and memories collectives and the gender.

The text that follows, articulates the different abandons, whether physical and symbolic experienced by the women's in its existential becoming, and manifested in the writing developed by the poets of southern Chile, seeking, mounted and dismounted new identities from the literary work.

\section{KEY WORD:}

Abandon, female poetic, guilt, assembly 


\section{NUESTROS PRIMEROS ABANDONOS}

¿De dónde viene el abandono? ¿De qué sustancia estará hecho? ¿Cómo romper el círculo de este sentimiento, si cuesta tanto resistir el miedo, a la soledad y al sufrimiento? ¿Debemos romper con el abandono o debemos aprender a vivir con él? ¿Será que las mujeres recién ahora, hemos sido conscientes de todo el abandono del cual hemos sido inventadas? ¿Por qué ignoramos todo de nuestros primeros instantes sobre este mundo? Quizás la naturaleza humana haya querido borrar nuestros primeros recuerdos para protegernos, prohibiéndonos de rememorar el primer abandono sufrido, para tomar posesión de la vida. El primer abandono sufrido al salir del vientre de nuestra madre, es una ruptura, una verdadera mutación, que define el primer verdadero pasado del individuo - doloroso recuerdo- que solo es posible superarlo a través de un cambio de registro, o en palabras de Benjamín, hacia un nuevo montaje, para poder llevar a cuestas el dolor provocado por el primer abandono de la vida.

Hélène Cixous, filósofa y feminista francesa hace una diferencia entre la interioridad del cuerpo y la interioridad psíquica, ésta que contiene la primera infancia, como si pudiésemos explorar a través del interior del cuerpo el origen enterrado: lo que ha olvidado la memoria. Cixous señala, que el cuerpo contiene la memoria del primer cuerpo (psíquico), que se remonta al cuerpo maternal, al cuerpo de antes, incluso antes del nacimiento. Esto es lo que uno puede leer, en un pasaje que reúne: expulsión, división, parto, mujer, feto, confundido y separado: “Una sola, adentro, coloreada yo soy una mancha de color contractada, ¿qué? Una que arde en el aire, volando, rojo pesado, o azul, quien sabe [...] entonces queda solo un ovalo blanco envuelto, creciendo inmóvil, suave, inmensa, duro negro duro brillante, casi muerta. De soledad"1 (Cixous, 1986: 125).

La autora describe la primera soledad vivida, el cuerpo perdido o la partícula de memoria borrada para siempre.

El primer abandono dialéctico, es aquel que se produce cuando sales del vientre de tu madre, la poeta Verónica Zondek², transmite de forma poética la experiencia del parto -abandono- del hijo y de sí misma, midiendo el largo de su soledad. La voz

1 Todas las citas de libros en Francés, son traducidos por la autora del artículo.

2 Verónica Zondek. Poeta y traductora. Licenciada en Historia del Arte en la Universidad Hebrea de Jerusalén. Ha participado en numerosos encuentros literarios, tanto en el país como en el extranjero. Ha formado parte del jurado de concursos como los del Consejo del Libro-Fondart. Ha sido publicada en muchas y diversas antologías de poesía de Chile y en el exterior. Sus poemas y artículos han aparecido en revistas de literatura tanto nacionales como extranjeras. Entre sus libros publicados se encuentran: El Libro de los Valles. Santiago: Ed. LOM, 2003. Entre Lagartas. Santiago: Ed. LOM, 1999. Membranza. Santiago: Ed. Cuarto Propio y Cordillera, 1995. Peregrina de mí. Santiago: Editorial Cuarto Propio, 1993. Vagido. Buenos Aires: Editorial Ultimo Reino, 1991. El Hueso de la Memoria. Buenos Aires: Editorial Ultimo Reino, 1988. La Sombra tras el Muro. Santiago, Ediciones Manieristas, 1985. Entrecielo y Entrelinea. Santiago: Ediciones Minga, 1984. femenina describe el parto que está centrado sobre el cuerpo femenino y el dolor que le produce la partida de su hijo. El motivo de la separación de dos cuerpos, en la cua la interioridad femenina -su cuerpo- aparece sobre la forma trágica, en el cual ella interpela el proceso de separación como de "muerte íntima". Bien lo escribe Zondek, en su libro Vagido (1991).

Mi guagua.
Sucia tu mano
tu cuerpo sucio
clamas la pena del abandono mío
tu sangre propia
tu piel sellada
tan entero en mano extraña
tu frío acierto
tu cierto miedo
tu vagido
desconcierto
ahí.
Para partirte niño
parto me doy
partiéndome
ahora
tuya
encuerpado otro
sangrándome mi mí
parto
parto partida
para partir parir descalza
como empezando.
Me encajo entera
y no me siento
tentándome al desgajo continuo
que voy dejándome
en el camino.
Llantería
para mi parir
parirte en grito
para en tu partida
partida dejarme
sin ti.

Por su parte Rosabetty Muñoz ${ }^{3}$, en su poema Mi útero rememora (1998), hace alusión al parto de uno de sus hijos, pero siempre retratando el vacío y la soledad provocado por éste proceso:

3 Rosabetty Muñoz. Poeta y profesora chilena, vinculada a los movimientos culturales Chaicura de Ancud, Aumen de Castro e Indice y Matra de Valdivia. Ha publicado: Canto de una oveja del rebaño, El Kultrun, Valdivia, 1981 ( $2^{\mathrm{a}}$ ed.: Ariel, Santiago, 1994). En lugar de morir, editorial Cambio, 1987. Hijos, El Kultrún, Valdivia, 1991. Baile de señoritas, El Kultrún, Valdivia, 1994. La santa, 
Los dientes del bisturí.

Se separa en gajos violáceos.

Me deslizo detrás de las columnas.

Escribo sobre mi vaho en los vidrios.

Quisiera quitarme los espejos

Que han pegado a mi paladar

Aquí ya no sirve la Esperanza.

Le dicen abandono

A esta similitud con la nada

Que nos rodea repentinamente.

El segundo abandono, se presenta terminada la gestación de la infancia, lo que implica encontrarse con lo solitario, se acaba la ingenuidad y aparece el sentimiento de lo precario: destierro, ausencia de la inocencia. Las modificaciones corporales hacen desaparecer del cuerpo "la imagen" de la pequeña niña, para hacer salir a la mujer. Debemos enterrar al niño o niña que se fue, surgiendo un destino fortuito que te deja en el mundo con una identidad confusa, obligada a vivir con una sangre mezclada que te tira de un lado hacia otro, sumiéndote en incontables y confusas contradicciones, en esas tinieblas en las que los seres humanos luchamos, para poder reconstruir una otra identidad. A veces, quisiéramos volver a esa inocencia, para no sentir la fragilidad, proceso que te lleva al borde de una ribera incierta y a una angustia de raíces lejanas...Recuerdos de la infancia relamidos y blanqueados de tanto lamer. De esta manera, la joven mujer debe separar su primer objeto de deseo, para reencontrarse a sí misma.

\section{Caer \\ es desvestirse y encontrarse con el alma \\ sentir emigraciones del nido \\ y el grito de los pájaros sin vuelo \\ que sueñan la eternidad en el fondo del ombligo. \\ (Roxana Miranda, del libro Las Tentaciones de Eva, 2010)}

Roxana Miranda Rupailaf ${ }^{4}$ expresa de manera completamente original este proceso, permitiendo cruzar la distancia que la separa de sí misma y de su madre, y que a la vez la mantiene en la infancia.

historia de una su elevación, LOM, Santiago, 1998. Sombras en El Rosselot, LOM, Santiago, 2002 Ratada, LOM, Santiago, 2005. En nombre de ninguna, El Kultrún, Valdivia, 2008. Polvo de huesos, antología elaborada por Kurt Folch; Ediciones Tácitas, Santiago, 2012

4 Roxana Miranda Rupailaf. Poeta Mapuche-Huilliche. Es profesora de Lengua Castellana y Comunicación, de la Universidad de Los Lagos. Ha publicado el libro Las Tentaciones de Eva editado por el Gobierno Regional de la Décima Región de Chile, 2003. Sus poemas han sido incluidos en las antologías Sur Fugitivo, Ediciones Jauría, 2003; Epu mari ulkantufe ta fachantu/20 poetas mapuche contemporáneos, Lom Ediciones, 2003; Canto a un prisionero. Antología de poetas americanos, homenaje a los presos políticos en Turquía, Editorial de poetas Antiimperialistas de América, Ottawa, 2005; Hilando en la memoria, Editorial Cuarto propio, 2006; Antología mapuche trilingüe, versiones en mapuchezungun, inglés y español, Editorial Five Islands Press, Australia, 2007; La memoria iluminada: poesía mapuche contemporánea, Ediciones Maremoto, España, 2007, Tierra Azul, Antología poética mapuche chileno argentina; Seducción de los venenos, Lom Ediciones 2008
El tercer abandono se produce cuando la joven mujer "eterna", debe abandonarse de una cierta forma de ella misma, cuando deviene madre o cuando se sacrifica por los otros: desarmar-se, abrirse-volver a armar-se, para re-aprender a ver.

Pensar la femineidad sobre los auspicios del sacrificio, es también pensar en la relación de la mujer al trauma singular o colectivo, que por ese evento ella se revela. En este sentido, el sacrificio es siempre un acto de desobediencia.

Anne Doufourmantelle, en su libro "La Femme et le Sacrifice", indica que, para una mujer, la cuestión del sacrificio es un exilio doble: "sacrificada y sacrificante, ella es la que se somete, y su cuerpo con ella, a un acto que la anula o la mutila obteniendo un otro lugar, una otra gloria [...] pero, es también la mujer sacrificante, ésta que destruye para derrumbar un mundo, que ella se sabe de antemano excluida" (Doufourmantelle, 2007: 33). En este proceso, la mujer -sacrificante- debe liberar o abandonar la "culpa original" ${ }^{5}$, superando ese sentimiento sumido a una atracción moral no enunciada.

\section{LA CULPA}

\section{La culpa. La culpa.}

Nos enseñan a hervir

Nos oprime el pecho.
(Rosabetty Muñoz, del libro La Santa, 1998)

La culpa, como señala Freud, es algo que acompaña la experiencia humana como una sombra (Freud, 1968: 30). Ella es sin duda la herencia de la humanidad. No solo nos lo recuerda la "Biblia" en el naturalizado relato del pecado original. Martin Heidegger y Karl Jaspers han propuesto con nuevos términos esta antigua temática de las religiones y de la especulación filosófica. Para el primero la culpa está en conexión con un "no", al no ser posible comprender "el dónde ni él debe" del hombre. Éste es expulsado del mundo en vista de un proyecto que, justamente para realizarse, exige que no se proyecte en otras posibilidades (Heidegger, 2015: 277). Para Heidegger, la culpa radica en lo infundado de la existencia. Jaspers, por su parte, coloca la culpa entre las situaciones límites de la existencia: tanto la acción como la no acción implican consecuencias, por lo tanto, en cualquier caso el ser es culpable (Jaspers, 1998: 68).

Freud, se inserta en esta importante corriente, pero desplazando el acento de la culpa al "sentimiento de culpa". En sus obras del primer período, como en "Los actos

5 La culpa original, desde el discurso Judeo-Cristiano señala que la mujer al comer la manzana fue castigada con el sufrimiento eterno, cargando la culpabilidad de haber desobedecido. Pero también, la mujer es culpable de haber introducido la sexualidad y el deseo, además de ser causante de la separación entre Dios y los hombres. Este discurso también se ve reflejado en los textos griegos, como el de Teogonía de Hesíodo en la fabricación de Pandora, la madre de todas las mujeres que porta el peligroso deseo. En estos textos, la mujer es la culpable de la pérdida original: el abandono del ser humano en el mundo. Por consecuencia necesitada de control y dominación. 
obsesivos y las prácticas religiosas", hace del sentimiento de culpa, la percepción de que el "yo" vendría a corresponder a la acción del Súper Yo -o bien a la crítica, a los reproches del Súper Yo- Instancia moral, que constituye la internalización de las normas, reglas y prohibiciones parentales (Freud, 1907: 97-109). Después de haber inicialmente situado el sentimiento de culpa en el inconsciente, Freud especificará resolviendo así la contradicción intrínseca al concepto de un sentimiento de culpa que se advierte pero que no es menos inconsciente- que la causa de la culpa es inconsciente y que solo sería consciente la sensación de culpabilidad.

La reflexión freudiana sobre el sentimiento de culpa procede de una gran cantidad de paradojas. De un lado, como nos enseña en "Tótem y Tabú", el sentimiento de culpa juega un rol esencial en la constitución de las sociedades humanas: aquí el sentimiento de culpa aparece como derivado de la represión del complejo de Edipo (Freud, 1980: 246). Por el contrario, en el Yo y en el Ello, el sentimiento de culpa más que construir parece subvertir el orden social. Otra importante paradoja de la culpa, es aquella por la cual la culpa no se aplaca por la rectitud y el respeto a la ley, dado que, como Freud lo subraya especialmente en "El malestar de la Cultura", cuanto más virtuoso es el individuo, más oprimido está por el sentimiento de culpa.

Lacan se mueve justamente desde aquí, desde este punto de llegada freudiano, señalando "se es culpable de una sola cosa, haber cedido en el propio deseo" (Lacan, 2003: 58). Sería necesario aislar la causa -absolutamente singular- de ese deseo del que no se debería ceder, para no ser tragados por los pantanos de la culpa.

\section{Me estremezco enroscada en el centro de la culpa. \\ Y vences \\ Y lo anuncias con atronadoras trompetas \\ (Rosabetty Muñoz, del libro En Lugar de morir, 1987)}

El proceso por el cual debemos arremeter para tratar de soltar estos sentimientos culpógenos, quizás es necesario ser misántropa y experimentar con paciencia "el deseo de ser amada y no poder serlo", como sostiene Carmen Martin Gaite "todo lo que vale la pena tarda uno en verlo y requiere sudores para sacarlo a pulso, pero nadie tiene por qué notar si ha costado mucho o poco el rescate" (Martin Gaite, 2002: 89). De alguna manera, experimentando el mundo a partir de un cierto exilio: abandonarse, desterrarse, desmarcarse, adentrarse en un ámbito aún por descubrir. Es en este proceso que deviene la escritura transformada en refugio, como un diálogo o monólogo interior, que otorga comprender la libertad por lo que las mujeres han combatido. Libertad, que significa la lucha de lo femenino con lo femenino, donde la revuelta se debe jugar al interior. Entonces, alguna cosa debe morir al interior de nosotras.

\section{AbANDONAR-SE, PUEDE ENTENDERSE COMO Un ¿SACRIFICIO O UN RENUNCIAMIENTO?}

La psicoanalista Anne Doufourmantelle, señala que el sacrificio no es un renunciamiento. El renunciamiento, según la autora "es la derrota del deseo, un deseo para la vida y para vivirlo, que va más allá de los límites de mi” (Doufourmantelle, 2007: 41). El sacrificio, en cambio, es una suerte de "sobre-deseo, que hace que un sujeto esté dispuesto a perderlo todo, para no perder lo esencial: honor e idéales, y ganar para sí o para los otros, la posibilidad de una otra vida, de una vida en la amplitud" (Doufourmantelle, 2007: 41). De esta manera, podemos entender el renunciamiento como la imposibilidad que tenemos las mujeres a desobedecer el orden parental o fraternal, mientras que el sacrificio traza un espacio fuera del sujeto, éste supone el espacio público de una comunidad unida por valores, leyes y de un mínimo de rituales que la componen. Por tanto, todo sacrificio es un "exilio fuera del campo habitual de las vidas cotidianas para ir a cuestionar a los dioses" (Doufourmantelle, 2007: 43). Esto puede ser el comienzo hacia un retorno al pasado, desmantelando los discursos naturalizados que han fabricado la historia, la iglesia y el Estado, situando a la mujer como causante de la culpa original:

La culpabilidad que la mujer busca reparar, para expiar su falta original, su bisexualidad original, de estar dotada de un órgano especializado en el placer, independiente de toda procreación [...] Las ha situado bajo la forma de una maternidad laudable que les ha quitado la libertad, llamando devoción a su libertad confiscada (Olivier, 1980: 123).

Romper con la manipulación que ha hecho el discurso dominante sobre la capacidad de sacrificio que tienen las mujeres por el cuidado de los otros y no por el sacrificio por ellas mismas, ha conducido a las mujeres a una búsqueda por la propia individualidad, renunciando a esto que la destina, para dar a su propia vida un otro sentido. El sacrificio aquí, es la necesidad de poner fin con el mundo arcaico y abrir una nueva ruta, inédita.

\section{DEJAR Y RECOMENZAR: REMONTAR EL ORIGEN}

El concepto de "Montaje" de Benjamín, nos ayuda a comprender esta nueva ruta que se debe trazar para rejuntar las imágenes literarias, como un acto de relectura y comparar los pasajes de vida. Montar y volver a remontar obliga a comparar y comprender, volver a descubrir. Montar como forma fragmentaria de escritura que aspira a una nueva construcción, “a comenzar desde el principio; a empezar de nuevo.. a construir desde poquísimo y sin mirar ni a diestra ni a siniestra" (Benjamín, 2005: 169). El montaje para Benjamín no es sólo un dispositivo estético, sino eminentemente una herramienta histórico-filosófica de primer orden. El concepto de "montaje", encierra la experiencia de una pérdida, donde la disolución del sentido se tiende a expresar con 
rasgos visuales ${ }^{6}$ (Benjamín, 2005: 89), que en nuestro caso se representa a través de la escritura poética.

Si Benjamín desplegó las estrategias del "montaje" para pensar tiempos de guerra, crisis y quiebre de sentidos (Didi-Hubermann, 2008: 97), parece adecuado plantear la pregunta para repensar la imagen fabricada de la "culpabilidad de la mujer", en tanto imagen arrancada del pasado, que retiene la génesis del Abandono. Desmontar el montaje es la tarea, que se instaló como una poderosa e iluminadora maquinaria histórica, e incluso una clara estrategia política. Para que esta tarea de escritura no aparezca naturalizada es que exhibimos su carácter de artificio y su dimensión política. La imagen escritural de nuestras poetas Verónica Zondek, Rosabetty Muñoz y Roxana Miranda Rupailaf, posan su mirada sobre lo no-sido o lo no dicho, y con el montaje intentan actualizarlo: porque saben que el pasado encriptado en el sueño de la historia debe ser despertado.

\author{
El terrible Cronos \\ Nos ha ido quitando el asombro \\ $Y$ la vergüenza. \\ El terrible Cronos \\ Nos empuja vida abajo \\ Donde la única verdad que permanece \\ Está clavada como las cruces en la tierra \\ (Rosabetty Muñoz, del libro En lugar de morir, 1987)
}

\section{De Cómo SE borda LA GÉNESIS DEL ABANDONO}

Si nos remitimos al mito de la Génesis, Adán asume el papel creador por excelencia. Por un lado, desde el punto de vista de la materialidad, la mujer se construye a partir de una de las costillas de Adán; y por otro, el acto de nominación que éste lleva a cabo, en cuanto ha sido dicha, designada o enunciada por el hombre.

El Señor Dios hizo caer sobre Adán un profundo sueño; y mientras estaba dormido le quitó una de las costillas, y llenó de carne aquel vacío. Y de la costilla aquella que había sacado de Adán, formó el Señor Dios una mujer: la cual puso delante de Adán.

Y dijo Adán: Esto es hueso de mis huesos, y carne de mi carne: llámese pues, hembra porque del hombre ha sido sacada. (Génesis., II, 21 a 24).

6 La imagen según Benjamín, siempre tiene un doble sentido: por un lado testimonia una petrificación (en la imagen se "detiene" o "suspende" el flujo de un acaecer vital) que remite a la cosificación capitalista. Pero también explora, en esa cosificación, las posibilidades de reacción ante ella. Pues esa imagen, "inquietud petrificada", coagula un flujo de energías políticas que en un momento propicio explota. La imagen recompone un nuevo sentido en un montaje que "salva" lo no-sido del pasado.
La construcción del linaje femenino, se ejecuta en torno de la noción de suplemento, apéndice, como una parte del todo. Resulta relevante que Adán, se constituya en e primer ser humano creado y que Eva, adquiera existencia en calidad de sujeta(a).

He creído conveniente, detenerme en este fragmento de la Biblia, porque el valor y la significación de este relato e imagen, han permanecido y siguen operando con fuerza y eficacia, en las matrices simbólico-discursivas de nuestra cultura.

El uso del poder que se hizo de la tesis del origen divino, por la iglesia Católica, pero también por los teóricos, fue la naturalización completa de las palabras fundadoras. De esta manera se erige la mítica Eva, la génesis del sujeto femenino como una construcción de lo otro (apéndice), la incompleta, la inacabada.

Siguiendo el mito de las "Sagradas Escrituras", según el Evangelio de San Juan como en el de San Mateo, Jesús es hijo de Dios (San Mateo 16,16) Simón Pedro contestó "Tú eres el Cristo, el Hijo de Dios vivo" (San Juan 1,49). De esta forma se edifica Jesúshombre como el Salvador, asignándole a su naturaleza un origen "celeste", "astral", "espiritual". De aquí emerge una de las problemáticas que nos interesa: el carácter "Divino" de Jesús, la reificación de la identificación real del hombre a Dios, que se encuentra reducida a una serie de apariencias, y al mismo tiempo, a la mistificación (Henry, 2000: 183).

Contra este discurso naturalizado de la condición divina del hombre, es que las mujeres han sido asignadas a una identidad y naturaleza menos digna de esa condición divina. La mujer fue construida a partir de una carne terrestre, y aún más, de un pedazo de esta carne: las costillas. Esto no fue azaroso, que la condición de la mujer haya sido establecida a partir de esta edificación absoluta, de una carne definida por su sufrimiento. El mito señala que fuimos construidas desde la pérdida, con el perjuicio de ser creadas en relación a la identidad de otro y esa inexistencia material y simbólica del objeto perseguido por ella, la conduce al reconocimiento de las pérdidas de su propia existencia, buscando continuamente la posibilidad de ser. Pérdida de la identidad propia y una pérdida de la divinidad.

De aguas y barbecho (Extracto del libro La Seducción de los venenos, Roxana Miranda)

$$
\begin{aligned}
& \text { La de los ojos cerrados } \\
& \text { y la manzana atorada en la garganta. } \\
& \text { Voluntariamente } \\
& \text { Abandona } \\
& \text { el prometido paraíso } \\
& \text { por la blanca fugacidad de los inviernos }
\end{aligned}
$$

Desde otra perspectiva, y como lo describe Roxana Miranda Rupailaf en el poema antes descrito, podemos entender el abandono como "dejar de lado", abortando los 
discursos, estructuras de pensamiento, de creencias o de sentimientos fabricados por el discurso falogocéntrico.

La deconstrucción y posterior resignificación de los mitos fundadores, como pérdida voluntaria para abrir espacios obliterados de la historia, como lo hizo Lilith quien abandonó el Edén por propia iniciativa ${ }^{7}$, seducida por otros caminos e imaginarios, "seducir (del latín seducere) significa desviar, atraer hacia sí, apartar del camino" (Baudrillard, 1981: 18).

¿Cómo escribir de nuevo, si lo que ha sido escrito y aprendido fue de manera incorrecta mil y una veces a través de la historia?

Esta partida, pérdida voluntaria o abandono de las escrituras naturalizadas, se desarrolla a partir del regreso al pasado, como en los mitos del "eterno retorno", volver a los orígenes, a ese estado paradisíaco para transformarlo. En este sentido, la escritura poética reactualiza la historia primordial, lo que implica un deseo de la mujer de retornar al mito de origen, como un anhelo de religarse con lo sagrado, y esto paradójicamente implica una ruptura previa, un desligamiento, un desprendimiento del cuerpo del origen que se traduce como una caída y abandono. Es así como, no sólo se debe volver al paraíso, para rememorar el abandono primordial, sino también para reactualizarlo con nuevos símbolos.

Evas $^{8}$ (del libro Seducción de los venenos, Roxana Miranda)

\section{Hágase la tierra.}

Le pondremos viento en el ombligo

y mar entre las piernas.

Hágase la luz y las estrellas.

En sueños celestes trasnochare para no ser vista.

7 El origen de la imagen de Lilit como la primera mujer de Adán, se encuentra en una interpretación rabínica de Génesis 1, 27. Antes de explicar que Yahveh dio a Adán una esposa llamada Eva, formada a partir de su costilla (Génesis 2:4-25), el texto dice: «Creó, pues, Dios al hombre a su imagen; a imagen de Dios lo creó; varón y mujer los creó». Si bien hoy suele interpretarse esto como un mismo hecho explicado dos veces, otra interpretación posible es que Dios creó en primer lugar una mujer a imagen suya, formada al mismo tiempo que Adán, y sólo más tarde creó de la costilla de Adán a Eva. La primera mujer a la que alude Gn. 1, 27 sería Lilit, la cual abandonó a su marido y el jardín del Edén. La única mención de Lilith en la Biblia aparece en Isaías 34:14. En la Biblia de Jerusalén el pasaje se traduce como: «Los gatos salvajes se juntarán con hienas y un sátiro llamará al otro; también allí reposará Lilit y en él encontrará descanso».

“Adán y Lilit nunca hallaron armonía juntos, pues cuando él deseaba tener relaciones sexuales con ella, Lilit se sentía ofendida por la postura acostada que él le exigía. « ¿Por qué he de acostarme debajo de ti? - preguntaba-: yo también fui hecha con polvo, y por lo tanto soy tu igual». Como Adán trato de obligarla a obedecer, Lilit, encolerizada, pronunció el nombre mágico de Dios, se elevó por los aires y lo abandono". En Posadas, Carmen y Sophie Courgeron. 2004. A la sombra de Lilith en busca de la igualdad perdida, Barcelona: Planeta.

8 Eva, que en palabra hebrea «Hhawwa » se relaciona con la maternidad, y que no está lejos de la palabra "serpiente" en arameo. Según la tradición bíblica, Eva es castigada y deberá parir con dolor y sufrimiento, Dios multiplicará sus penas: el apetito del deseo la perseguirá por siempre y la dominará.
Háganse los peces, los animales, las aves.

Multiplíquense y habiten el reino de mis caderas.

Háganse las flores y los frutos

para simular la fiesta.

Hágase el hombre del barro de mi garganta

que de la saliva salga a cantar.

Hágase la mujer a mi imagen

con la divina dulzura del lenguaje.

Con el poema Evas, Roxana Miranda realiza una sutil operatoria de socavamiento, mediante una aparente estrategia de reproducción literaria, donde estructura y discurso bíblico se transmutan en recursos literarios constituyentes de otra semiosis; "desolcultar los códigos de transparencia que borran el trabajo significante de las ideologías culturales, es la primera maniobra de resistencia crítica al falso supuesto de la neutralidad de los signos" (Richard, 1993: 56)

Vemos como Miranda Rupailaf, despliega a la manera del libro "sagrado", una nueva génesis, que funciona polisémicamente en diversos planos: como desvío enunciativo a nivel de la narración; como transgresión, en el nivel de la historia, y como autorreferencialidad y metarrelato, en la dimensión de la escritura de las mujeres. En el desvío enunciativo, se puede percibir en la desautorización de la palabra fundacional, repitiendo insistentemente en sus narrativas. Esta voluntad de reiterar, busca un itinerario de eficacia simbólica, para desmontar las piezas del logo bíblico y haciendo visible la subjetividad clausurada. En esta nueva Génesis, se expone una perspectiva semiótica, ofreciendo la síntesis de los procesos creativos, transgrediendo los mandatos, ya que quien enuncia es una mujer y que ejerce la Ley sobre los orígenes del universo y las criaturas, argumentación axial en el nivel de la historia y en el nivel del discurso, que aborda la encrucijada cultural en el tratamiento de los problemas de género y de su relación con el uso de la palabra: la relación entre mujer y poder.

Miranda Rupailaf, reescribe la historia en este poema, desde una perspectiva de liberación. Eva ya no está sometida a la reproducción, ni a la falta de palabra, ni a la culpabilidad de una culpa inicial, que ha estado fatalmente transmitida durante siglos. Los grandes relatos que han gobernado a las mujeres, sobre todo el gran relato mítico de la biblia, en la cual Eva es instalada sobre una historia terrorífica de nuestros orígenes, donde el prolongamiento de este relato ha trabajado nuestras mentalidades a través de los siglos y a través de la locución, lenguaje que ha estado reservado a los hombres.

Esa es la difícil labor de la escritura: dar en el lenguaje del mundo, los mensajes que vienen de las profundidades y que desafían la palabra. 


\section{LA AUSENCIA, COMO MECANISMO DE DESVIACIÓN}

Activar los recuerdos constituye en sí mismo, una práctica política, llevada a cabo por todos los sujetos sociales, en distintos grados y formas, ya sea desde una condición traumática ${ }^{9}$ (Edkins, en línea), desde lo ominoso, desde la culpa o desde el abandono. Pero, sobre todo activar los recuerdos es "enfrentar el pasado". Muchas veces este retorno al pasado representa un trance demasiado doloroso, y ante ello los individuos optan por evadirlo o posponerlo indefinidamente, ya que no logran encontrar un canal simbólico o una forma expresiva de comunicación para expresarlo.

El historiador Dominick LaCapra, en su libro "Escribir la historia, Escribir el Trauma", traza una diferencia entre ausencia y pérdida. Si bien, la pérdida genera sentimientos de ausencia, ésta última no depende de una pérdida pues puede acontecer al margen de un evento fundante. En términos simples, no se puede perder lo que nunca se ha tenido: "la ausencia se aplica en general a fundaciones definitivas, particularmente a bases metafísicas...la ausencia es la falta de un absoluto, el que no debería ser absolutizado o fetichizado" (LaCapra, 2005: 42). En dicha línea, los mitos fundacionales, ya sean los que se relacionan con el origen de lo individual, lo comunitario nacional, o la humanidad son en verdad una respuesta a una ausencia, más que a una pérdida (LaCapra, 2005: 5051). Sin embargo, a menudo en esta dinámica de desplazamientos mutuos la ausencia es tratada como pérdida, lo cual lleva a incrementar "las posibilidades de una nostalgia extraviada, o utopías políticas en busca de una nueva totalidad, o de una comunidad totalmente unificada" (LaCapra, 2005: 47). Con esto, se lleva a imaginar un estado de plenitud anterior a todo pecado original, un paraíso perdido que ha colapsado ante el advenimiento de la diferencia y del conflicto. Por el contrario, cuando la pérdida se convierte, o es articulada mediante una retórica de la ausencia, "se enfrenta el impasse de una melancolía interminable, un duelo imposible, en donde cualquier posibilidad de enfrentar el pasado y sus pérdidas históricas colapsan o abortan prematuramente" (LaCapra, 2005: 46).

9 "Lo que denominamos trauma, tiene lugar cuando los mismos poderes que creemos que van a protegernos y darnos seguridad se convierten en nuestros verdugos: cuando la comunidad de la cual nos consideramos miembros se vuelve en contra nuestra, o cuando nuestra familia ya no es un fuente de refugio, sino un lugar de peligro...si ese orden nos traiciona de alguna forma, podemos sobrevivir en el sentido de continuar como seres físicos, pero el significado de nuestra existencia cambia". Por otra parte, resulta útil señalar la distinción que realiza Pierre Janet entre la memoria habitual o implícita y la memoria narrativa, esta es aquella que mediante evaluaciones subjetivas permite darle sentido a la experiencia cotidiana, en la medida en que construye estructuras mentales paradigmáticas que sirven para acoger experiencias habituales. La memoria narrativa, por lo tanto exige un trabajo de conciencia y, por lo mismo, es un acto social en la medida que su construcción ocurre en un contexto de convenciones y acuerdos sociales prexistentes. De este modo, las experiencias familiares y cotidianas se integran de manera más o menos automática, no así aquéllas extrañas y amenazadoras, las cuales lo hacen con mayor dificultad o se resisten de ser asimiladas. En Janet, Pierre. L'evolution de la memoire et de la notion du temps. Editions L'Harmatan, France, 2006
Lo que sostiene el autor, es que este mecanismo de traslación de la pérdida en ausencia lleva a evitar lo histórico, al transformar las pérdidas concretas en ausencias etéreas, lo que sirve a propósitos políticos para no enfrentar las pérdidas históricas al ubicarlas bajo un manto generalizado de "ausencia".

La ausencia posee, según el autor, una naturaleza transhistórica, lo que convierte en irrelevante las demarcaciones histórico-temporales. La pérdida, no obstante se asienta totalmente en lo histórico, el pasado es su escenario y por tal motivo está siempre inscrito en un evento específico que involucra pérdida de vidas y culturas, y como tal, dichos eventos pueden ser visitados, reactivados, e interpretados con miras a transformar el presente y el futuro. Finalmente, al trasladar pérdidas concretas al ámbito de la ausencia, lo que se logra es normalizar las faltas y vacíos para evaluarlos como inevitables, parte rutinaria y regular de la existencia. Siguiendo esta lógica, la pérdida con frecuencia se confunde con la "carencia", esto es, la sensación abrumadora de que algo que debería estar y ya no está, lo que puede conducir a intentar compensar dicho vacío recurriendo a múltiples mecanismos, los que posponen indefinidamente en encuentro con la pérdida real (LaCapra, 2005: 57).

Ahora bien, este razonamiento nos lleva a entender cuál es el papel que juega la construcción del abandono este escenario. Si las mujeres estamos hechas de "abandono", desde épocas primigenias, discurso abalado por los mitos creacionistas y por la historia. Es precisamente gracias a estos procesos que han desarrollado algunas mujeres poetas e intelectuales, a través de un pensamiento solitario y reflexivo, es que ha sido posible activar los recuerdos y enfrentar el pasado, develando la maquinación. Comprender el abandono como pérdida y no como ausencia metafísica, se hace posible superar el pasado, en este caso superar la instalada "culpa histórica de la mujer", lo cual involucra asumir una distancia crítica con el propio "yo", ya que precisamente lo que estaba instalado en el discurso "falogocéntrico" era el abandono articulado mediante una retórica de la ausencia, caracterizada por una naturaleza transhistórica, por tanto, la operación discursiva y psicológica, que trata el abandono como ausencia resulta del todo oportuna para desvincular los hechos y las motivaciones históricas que las provocaron.

Frente a esto, encarar el abandono como pérdida involucra negar el Edén primordial, negar el discurso que ha naturalizado la victimización de la mujer como de "habituación moral". Es decir, negar el discurso que instaló a la mujer como la culpable de todo mal y de todo abandono, y que además se otorga el derecho de "salvarla de sus culpas", a una culpable que él mismo ha fabricado.

Situar el abandono como pérdida, podremos reponer el hilo que une a la actualidad con el pasado y el futuro. En este contexto, la poesía y los lenguajes simbólicos no 
atenidos a ordenanzas de "logicidad", se presentan como los medios idóneos para comunicar y ayudar a rescribir una nueva memoria del abandono.

La escritura de mujeres poetas, como Verónica Zondek, Rosabetty Muñoz, y Roxana Miranda Rupailaf, citadas en este trabajo, al trasladar su discurso al texto-cuerpo, en alguna medida van trizando el carácter jerárquico-histórico de la cultura patriarcal (Moraga, en línea) a través del des-doblamiento de los pliegues del lenguaje, en un acto íntimo de recuperar identidades, desde ellas mismas y ya no desde el "otro". Esta apertura que anuncian nuestras poetas: la transitoriedad entre pasado -espacio asignado- y presente -espacio elegido- (Moraga, en línea) va construyendo un otro lugar, un territorio interior, desde donde se interroga para reabrir la memoria al lenguaje, donde se re-presentan los conflictos para reconocer y reconciliarse con las historias y con las memorias de las vivencias abandonadas.

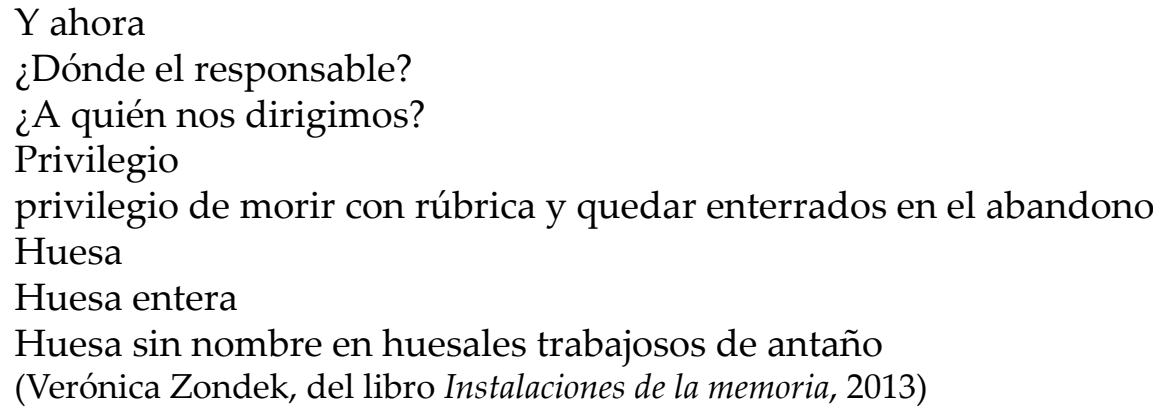

Las obras y las trayectorias que desarrollan estas poetas a través de su escritura brindan una perspectiva que recompone las particularidades de un conjunto de sujetas y experiencias no del todo representadas por la categoría "mujeres", ya que estas autoras en sus obras, tensionan, atraviesan e inclinan sus tránsitos y trayectos en torno a rescribir otras historias, no contadas por la historiografía oficial, reinventando mitos, analizando cómo opera el discurso en la "creación", "invención" y "fundación" de los discursos dominantes.

De esta manera surgen otras historias: de indígenas, mujeres, gays, lesbianas, migrantes. Otras voces instantáneas y subalternas, que como dice Homi Bhabha "van más allá, habitando un espacio 'entre tiempos', haciendo parte de un tiempo revisionario, de un retorno al presente por re-escribir nuestra contemporaneidad cultural" (Bhabha, 2007: 38), y es aquí en ese "más allá", que transforma el presente, la mujer soltó algo: abandonó el miedo a su representación arcaica.

Yo, Pecadora (Roxana Miranda, del libro Las tentaciones de Eva)

Confieso que he robado el alma al corazón de Cristo,

que maté a una flor por la espalda

y le disparé a la cigüeña.

Confieso que me comí todas las manzanas

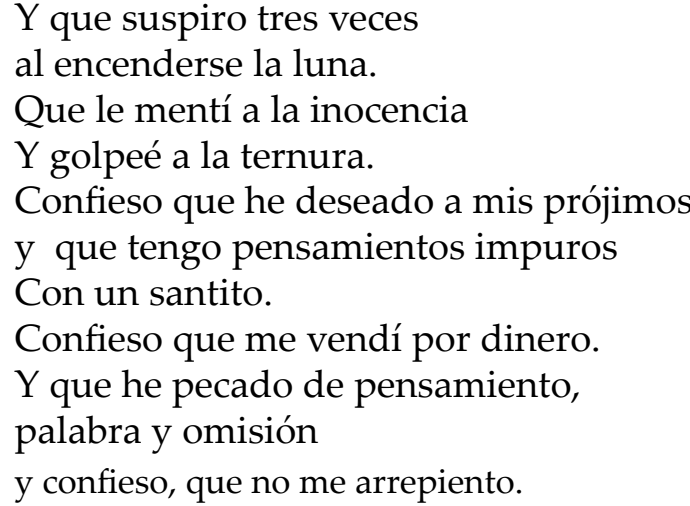

A través de estas enunciaciones poéticas, que van movilizando elementos ideales y materiales, dan prueba de la vitalidad del discurso que han hecho uso las mujeres estos últimos años, produciendo la "visibilidad", y la "reinvención" de la historia, yendo más-allá de lo ya escrito. Si tenemos memoria para recordar, y rehacer, recortar, cortar, volver a montar, remontar el erigen y ponerlo al servicio de la creación poética, para de esa manera abandonar historias naturalizadas, y crear otras nuevas, donde podamos significarlas nuevamente en nuestros procesos de pérdidas históricas. Esta poética del abandono, debe permanecer en el espíritu del "derecho a decir", como medio de alcanzar la propia identidad. Para esto, es necesario revisar los mitos de pertenencia, como "puntos de partida", conectándolo con otras historias interiores y exteriores, situándose como señala Bhabha en un "mas-allá", encontrando sus ambivalencias y ambigüedades, debiendo repetir, separar y cortar las representaciones y así recuperar la historia no contada de las mujeres.

\section{ReFERENCIAS Bibliográficas}

Baudrillard, J., De la seducción. Traducción de Elena Benarroch. Madrid, Ediciones Cátedra, 1981.

Benjamín, W., Libro de los Pasajes, Madrid, Akal, 2005.

Bhabha, H., Les Lieux de la Culture. Une Théorie Postcoloniale. Paris, Editions Payot, 2007.

Cixous, H., Dedans. Paris, Editions des Femmes, 1986.

Didi-Huberman, G., Cuando las imágenes toman posición. El ojo de la historia, 1, Madrid, Machado Libros, 2008.

Dufourmantelle, A., La Femme et le sacrificie. D'Antigone à la femme d'à côté. París, Editions Denoël, 2007.

Edkins, J., Trauma and the memory of politics. Cambridge, Cambridge University Press, 2003. Internet. 05-11-2016. <www.books.google.cl/books?isbn=0521534208>.

Freud, S., "El malestar en la cultura", en Obras Completas, Madrid, Editorial Biblioteca Nueva, vol. III, 1968. 
Freud, S., “Acciones obsesivas y prácticas religiosas”. En Obras completas. Vol. IX, 1907. Internet. 08-11-2016. <http://descargas.dos-teorias.net/textos/sigmund-freud/etcheverry/ volumen-09>.

Freud, S., “Tótem y Tabú y otras obras (1913-1914)”, en Obras completas, Vol XIII. Madrid, Amorrortu, 1980.

Heidegger, M., Ser y Tiempo. Traducción de Jorge Rivera. Santiago, Editorial Universitaria, 2015.

Henry, M., Incarnation. Une philosophie de la Chair. Paris, Editons du Seuil, 2000.

Janet, P., L'evolution de la memoire et de la notion du temps. Paris, Editions L'Harmatan, 2006.

Lacan, J., El Seminario, Libro 5: Las formaciones del inconsciente. Buenos Aires, Paidós, 2003.

Jaspers, K., El problema de la culpa: sobre la responsabilidad política de Alemania. Barcelona, Ediciones Paidós Ibérica, 1998.

LaCapra, D., Escribir la Historia, Escribir el Trauma. Buenos Aires, Nueva Visión, 2005.

Martin Gaite, C., Cuadernos de todo. Barcelona, Ediciones Debate, 2002.

Miranda Rupailaf, R., Las tentaciones de Eva. Ediciones Sec. Regional Ministerial de Educación, Región de Los Lagos. Santiago, Colección Premios Luis Oyarzún, 2003.

Miranda Rupailaf, R., Seducción de los venenos. Santiago, LOM Ediciones, 2008.

Miranda Rupailaf, R., Las Tentaciones de Eva ( $2^{\circ}$ Ed.), Temuco, Ripio Ediciones, 2010.

Moraga, F., La Bandera de Chile: (Des)pliegue y (des)nudo de un cuerpo lengua(je). Acta literaria, (26), 89-98, 2001. Internet. 27-03-2015. <http://www.scielo.cl/scielo. php?script=sci_arttext\&pid=S0717-68482001002600007\&lng=es\&tlng=es. $\quad 10.4067 /$ S0717-68482001002600007>.

Muñoz, R., La Santa. Historia de su elevación. Santiago, LOM Ediciones, 1998.

Muñoz, R., En lugar de morir. Santiago, Editorial Cambio, 1987.

Olivier, C., Les enfants de Jocaste, l'empreinte de la mère. Paris, Denoël-Gonthier, 1980

Posadas, C., y Courgeron S., A la sombra de Lilith: en busca de la igualdad perdida, Barcelona, Planeta, 2004.

Richard, N., "La política de los espacios: crítica cultural y debate feminista", en Masculino/ Femenino. Santiago, Francisco Zegers Editor, 1993.

Zondek, V., Vagido. Bs. Aires, Editorial Último Reino, 1991.

Zondek, V., Instalaciones de la memoria. Santiago, Alquimia Ediciones, 2013. 